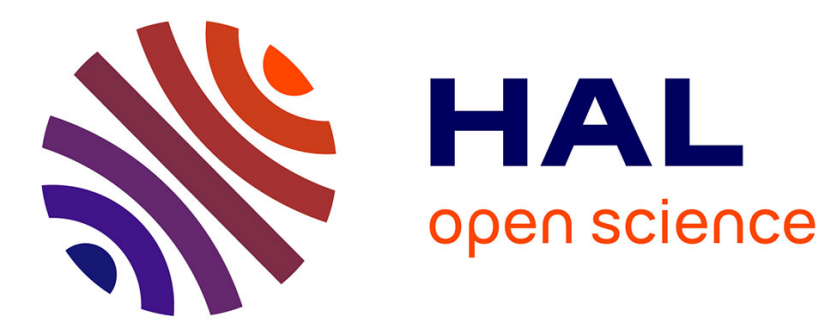

\title{
Respiratory onset in an ALS family with L144F SOD1mutation
}

Philippe Corcia, Philippe Petiot, Zorica Stevic, Patrick Vourc'H, Raoul Morales, Paul Gordon, Nicolas Pageot, Christian Andres, William Camu

\section{- To cite this version:}

Philippe Corcia, Philippe Petiot, Zorica Stevic, Patrick Vourc'H, Raoul Morales, et al.. Respiratory onset in an ALS family with L144F SOD1mutation. Journal of Neurology, Neurosurgery and Psychiatry, 2010, 82 (7), pp.747. 10.1136/jnnp.2009.197558 . hal-00600748

\section{HAL Id: hal-00600748 \\ https://hal.science/hal-00600748}

Submitted on 16 Jun 2011

HAL is a multi-disciplinary open access archive for the deposit and dissemination of scientific research documents, whether they are published or not. The documents may come from teaching and research institutions in France or abroad, or from public or private research centers.
L'archive ouverte pluridisciplinaire HAL, est destinée au dépôt et à la diffusion de documents scientifiques de niveau recherche, publiés ou non, émanant des établissements d'enseignement et de recherche français ou étrangers, des laboratoires publics ou privés. 


\section{Respiratory onset in an ALS family with L144F SOD1mutation}

P Corcia MD, $\mathrm{PhD}^{1}, \mathrm{P}$ Petiot $\mathrm{MD}^{2}, \mathrm{Z}$ Stevic $\mathrm{MD}, \mathrm{PhD}^{3}$, $\mathrm{P}$ Vourc'h $\mathrm{PhD}^{4}, \mathrm{R}$ Morales $\mathrm{MD}^{5}, \mathrm{PH}$ Gordon $\mathrm{MD}^{6}, \mathrm{~N}$ Pageot $\mathrm{MD}^{5}, \mathrm{C}$ Andres MD,PhD ${ }^{4}, \mathrm{~W}$ CamuMD, $\mathrm{PhD}^{5}$.

1 - Centre SLA, CHU de Tours, France

2- Service d'Explorations Neurologiques, Hôpital de la croix rousse, CHU de Lyon, France

3 - Institute of Neurology, Clinical Center of Serbia, University of Belgrade, Belgrade, Serbia

4 - Laboratoire de Biochimie et Biologie moléculaire, Inserm U930, CHU de Tours, France

5-Centre SLA, CHU de Montpellier, Université Montpellier 1, France

6: Northern Navajo Medical Center, Shiprock, New Mexico USA

Correspondance to : W Camu, Clinique du Motoneurone, CHU Guy de Chauliac, Université Montpellier 1, 34295 Montpellier CEDEX 5. Fax number : +33 467607413

e-mail address : w-camu@chu-montpellier.fr

Key words: Familial ALS-SOD1-Respiratory 


\section{Summary:}

Familial amyotrophic lateral sclerosis (FALS) cases linked to SOD1 mutations may sometimes present with unusual clinical features such as pure lower motor neuron involvement or sensory signs.

We describe a FALS pedigree with the L144F SOD1 mutation in which all cases had respiratory involvement as a first symptom.

Although atypical clinical features are not rare in ALS families, this is the first pedigree with respiratory-onset in three affected members. This unusual presentation led to delayed diagnosis in the proband and highlights the fact that respiratory-onset can occur in familial ALS cases carrying SOD1 mutation.

Key words : Familial ALS-SOD1-respiratory onset. 


\section{Introduction:}

Amyotrophic lateral sclerosis (ALS) is a devastating disorder of unknown origin. In approximately $20 \%$ of cases, familial aggregation occurs.(1) 12 to $23.5 \%$ of patients with a diagnosis of familial ALS (FALS) and 0 to $7.3 \%$ of patients with a diagnosis of sporadic ALS have in different populations been associated with a SOD1 gene mutation.(2) More recently, other genes have been implicated but account for less than $10 \%$ of FALS.(3) To date, more than 130 SOD1 mutations have been identified and some atypical phenotypes have been described such as 1) a long duration, more than 10 or 20 years,(4) 2) pure lower motor neuron disease,(5) or 3) sensory or oculo-motor signs.(6-7) Phenotypic heterogeneity within families has also been shown. Respiratory-onset is usually rare in ALS, accounting for less than 5\% of cases.(8)

Here we present, to our knowledge, the first ALS family with respiratory-onset and SOD1 mutation. All affected family members had respiratory muscle weakness as the first symptom.

\section{Case reports:}

A 54 year-old man was referred to our center in August 2007, because of an eight month-history of intense fatigue, dyspnea and orthopnea. At the first visit in January 2007, the neurological examination was normal in the bulbar region and the four limbs without clinical signs for upper motor neuron and lower motor neuron involvement conversely to pulmonary investigation that indicated the need for nocturnal non-invasive ventilation (NIV). At that time, slow vital capacity was $44 \%$ and forced vital capacity was $47 \%$ of normal values. The 
March 2007, his neurologist only noted intense fatigue. In June, the patient complained of dyspnea and electromyography showed normal conduction velocities with low CMAP amplitudes in the legs together with denervation at needle examination. Respiratory involvement progressed and non invasive ventilation was required in July 2007. When he was first seen for in our department, the ALSFRS-R scale was scored 32/48. On physical examination, there were both upper and lower motor neuron signs in the right upper and lower limbs with brisk tendon reflexes, fasciculations and moderate amyotrophy. The plantar response was flexor on both sides. Nerve conduction studies were normal, but needle EMG showed severe denervation and fibrillations in all four limbs. Disability progressed rapidly, and the ALSFRS-R scale was rated 22/48 in January 2008. In September, the patient had severe tetraparesis as well as bulbar palsy with dysphonia, dysphagia, paresis of the tongue, vocal cords and pharyngeal muscles. NIV was used both during night and day.

This patient indicated that his mother died at 83 years of age in 2004 after several years of progressive motor impairment. Her medical history was obtained from her file. Her ALS began with dyspnea in 1990 and NIV was started in 1994. By 2000 she had moderate weakness in the four limbs together with axial involvement. At that time neurological examination showed for the first time both upper and lower motor neuron signs both in bulbar and limb muscles. Nerve conduction studies were normal and needle EMG showed diffuse denervation. She used a walker because of lumbar paraspinalis muscles weakness. In 2002, hypercapnia was noted (pCO2 50mmHg) despite ventilation. She died in 2004 after 14 years of ALS. The formal diagnosis of ALS was suspected but could not be ascertained by her neurologists because of the atypical respiratory onset and the slow evolution. 
The maternal uncle of the proband, A Serbian man who lived in Belgrade, developed dyspnea followed by diffuse amyotrophy at age of 65 . His clinical state progressively worsened and he died after 5 years of symptoms (figure 1).

Two living siblings of our proband were examined both clinically and neurophysiologically without findings suggestive of ALS. A third sibling died of heart ischemia.

\section{SOD1 gene analysis:}

After written informed consent, blood was collected and DNA extracted from our proband. Five exon portions and flanking splice junctions of the SOD1 gene were amplified by PCR as previously described.(9) PCR products were sequenced in both strands and analyses were done with sequence analysis software against sequences of reference GeneBank: L44135 to L44139. Mutational analysis revealed a missense mutation in exon 5 Leu144Phe-(L144F) (Figure 2).

\section{Discussion:}

The L144F mutation was one of the first SOD1 mutations found in ALS.(10) Since that time three L144F FALS pedigrees have been described which shared several characteristics, including origin from western Mediterranean countries (Italy and IstroRumania), slow evolution and a predominantly lower limb onset (Table 1). Cognitive involvement has also been described in these families and, although rare, this was the first SOD1 mutation in which dementia was shown [case V-4 (11); case IV-6(12)]. 
In our family, the disease was characterized by respiratory-onset, contrasting with other SOD1-linked FALS pedigrees, with or without the L144F mutation. The frequency of respiratory-onset in ALS is estimated between 2.7 and $5 \% .(8,13)$ This unusual presentation may explain the delayed diagnosis in the mother. In her case, ALS was initially excluded because of the predominant respiratory impairment and the slow evolution, but the medical file was clear enough to indicate the respiratory onset and clinical signs of upper and lower motor neurons with abnormalities at EMG typical of ALS. Descriptions of the third patient, the proband's uncle were considered convincing but despite our inquiries and study of data bases in Serbia, his clinical file could not be obtained.

Our family originated from Serbia, a country near Italy and Rumania. Other SOD1 mutations also originate from specific countries: the $\mathrm{A} 4 \mathrm{~V}$ mutation is frequent in the United States but associated with an Italian origin,(14) the D90A mutation originates from Sweden,(6) and the R115G mutation is found exclusively in the German population.(15) Although not genetically ascertained, L144F may originate from Serbia as 17 families carrying the mutation have been identified there (unpublished data), while single pedigrees or cases have been found in surrounding countries.

Although a significant number of patients with SOD1 mutations have limb and particularly lower limb onset, the presented family highlights the fact that respiratory onset can occur in familial ALS linked to SOD1 mutation. Physicians should be aware of that possible feature as, in at least two of our three cases, the diagnosis was delayed or not confirmed until late in the course of the disease. 


\section{Competing Interest: None declared.}

Copyright Licence for Publication:

The Corresponding Author has the right to grant on behalf of all authors and does grant on behalf of all authors, an exclusive licence (or non exclusive for government employees) on a worldwide basis to the BMJ Publishing Group Ltd to permit this article (if accepted) to be published in PMJ and any other BMJPGL products and sublicences such use and exploit all subsidiary rights, as set out in our licence. (http://group.bmj.com/products/journals/instructions-for-authors/licence-forms). 


\section{References:}

1 Kurland LT, Mulder DW. Epidemiologic investigations of amyotrophic lateral sclerosis: Familial aggregations indicative of dominance inheritance I. Neurology 1955;5:182-196.

2 Andersen PM. Amyotrophic Lateral Sclerosis associated with mutations in the CuZn superoxide dismutase gene. Curr Neurol Neurosci Rep 2006;6:37-46. Rosen DR, Siddique T, Patterson D, et al. Mutations in $\mathrm{Cu} / \mathrm{Zn}$ superoxide dismutase gene are associated with familial amyotrophic lateral sclerosis. Nature. 1993;362:59-62

3 Valdmanis PN, Daoud H, Dion PA, et al. Recent Advances in the Genetics of Amyotrophic Lateral Sclerosis. Current Neurology and Neuroscience Reports 2009, 9: 198 - 205

4 Aoki M, Ogasawara M, Matsubara Y, et al. Mild ALS in Japan associated with novel SOD mutation. Nat Genet 1993;5: 323-324.

5 Cudkowicz ME, McKenna-Yasek D, Chen C, et al. Limited corticospinal tract involvement in ALS subjects with the A4V mutation in the Cu/Zn SOD1 gene. Ann Neurol 1998;43:703710.

6 Andersen PM, Forsgren L, Binzer M, et al. Autosomal recessive adult-onset amyotrophic lateral sclerosis associated with homozygosity for Asp90Ala $\mathrm{Cu}, \mathrm{Zn}$ superoxide dismutase mutation. A clinical and genealogical study of 36 patients. Brain 1996;119:1153-1172.

7 Ikeda M, Abe K, Aoki M, et al. Variable clinical symptoms in familial amyotrophic lateral sclerosis with a novel point mutation in the $\mathrm{Cu} / \mathrm{Zn}$ superoxide dismutase gene. Neurology $1995 ; 45: 2038-2042$.

8 Schoesmith C, Findlater K, Rowe A, et al. Prognosis of amyotrophic lateral sclerosis with respiratory onset. J Neurol Neurosurg and Psychiatry 2007;78:629-631.

9 Mayeux V, Corcia P, Besson G, et al. N19S, a new superoxide dismutase gene mutation in sporadic amyotrophic lateral sclerosis: No evidence for disease causation. Ann Neurol 2003;53:815-818. 
10 Deng HX, Hentati A, Tainer J, et al. ALS and structural defects in Cu,Zn SOD. Science 1993;261: 1047-1051.

11 Masè $\mathrm{G}$, Ros S, Gemma A, et al. ALS with variable phenotypes in a 6 generation family caused by Leu144Phe mutation in the SOD1 gene. J Neurol Sci 2001;191:11-18.

12 Ferrera L, Caponnetto C, Marini V, et al. An Italian dominant FALS Leu144Phe SOD1 mutation: genotype-phenotype correlation. Amyotroph Lateral Scler 2003;4;167-170.

13 Argyriou AA, Polychronopoulos P, Papapetropoulos S, et al. Clinical and epidemiological features of motor neuron disease in South-western Greece. Acta Neurol Scand 2005;111:108113.

14 Cudkowicz ME, McKenna-Yasek D, Sapp PE, et al. Epidemiology of mutations in superoxide dismutase gene in amyotrophic lateral sclerosis. Ann Neurol 1997;41:210-221. 15 Niemann S, Joos H, Meyer T, et al. Familial ALS in Germany: origin of the R115G SOD1 mutation by a founder effect. J Neurol Neurosurg Psychiatry 2004;75:1186-1188. 
Table 1: Clinical features of L144F (according to the new classification) SOD1 ALS patients

\begin{tabular}{|c|c|c|c|c|c|}
\hline Origin & Gender & Age of onset (SD) & Site of onset & ALS duration (SD) & References \\
\hline $\begin{array}{l}\text { Italy } \\
\text { Italy }\end{array}$ & $\begin{array}{l}M \\
M\end{array}$ & $\begin{array}{l}53 \mathrm{yrs} \\
51 \mathrm{yrs}\end{array}$ & $\begin{array}{l}\mathrm{LL} \\
\mathrm{LL}\end{array}$ & & Alsod.org \\
\hline Italy & $M$ & $50 \mathrm{yrs}$ & UL & & \\
\hline Italy & $\mathrm{F}$ & $55 \mathrm{yrs}$ & UL & & \\
\hline Italy & $\mathrm{M}$ & $64 \mathrm{yrs}$ & LL & & \\
\hline Italy & M & $24 \mathrm{yrs}$ & LL & & \\
\hline Istro-Rumania & $\mathrm{M}$ & 49 yrs & UL & $1.5 \mathrm{yrs}$ & Masè \\
\hline Istro-Rumania & $\mathrm{M}$ & $51 \mathrm{yrs}$ & LL & $6 \mathrm{yrs}$ & \\
\hline Istro-Rumania & M & $58 \mathrm{yrs}$ & LL & 7 yrs & \\
\hline Istro-Rumania & $\mathrm{F}$ & $72 \mathrm{yrs}$ & LL & $5 \mathrm{yrs}$ & \\
\hline Istro-Rumania & $\mathrm{F}$ & $66 \mathrm{yrs}$ & LL & $6 \mathrm{yrs}$ & \\
\hline Istro-Rumania & $\mathrm{F}$ & $67 \mathrm{yrs}$ & UL & $13 \mathrm{yrs}$ & \\
\hline Istro-Rumania & $\mathrm{F}$ & $47 \mathrm{yrs}$ & LL & $4 \mathrm{yrs}$ & \\
\hline Istro-Rumania & M & $54 \mathrm{yrs}$ & LL & 4 yrs & \\
\hline Istro-Rumania & $\mathrm{F}$ & $54 \mathrm{yrs}$ & LL & $1 \mathrm{yrs}$ & \\
\hline Italy & $\mathrm{F}$ & $18 \mathrm{yrs}$ & $\mathrm{LL}$ & 4 yrs & Ferrerra \\
\hline Italy & $\mathrm{F}$ & $63 \mathrm{yrs}$ & LL & $10 \mathrm{yrs}$ & \\
\hline Italy & $\mathrm{F}$ & $38 \mathrm{yrs}$ & LL & $8 \mathrm{yrs}$ & \\
\hline Italy & $\mathrm{F}$ & 33 yrs & LL & $34 \mathrm{yrs}$ & \\
\hline Italy & M & $67 \mathrm{yrs}$ & LL & $2 \mathrm{yrs}$ & \\
\hline Italy & $\mathrm{F}$ & $64 \mathrm{yrs}$ & LL & $8 \mathrm{yrs}$ & \\
\hline Italy & $\mathrm{F}$ & $72 \mathrm{yrs}$ & LL & 2 yrs & \\
\hline Serbia & $\bar{M}$ & $54 \mathrm{yrs}$ & Respiratory & Still Alive & Corcia \\
\hline Serbia & $\mathrm{F}$ & & Respiratory & $14 \mathrm{yrs}$ & \\
\hline Serbia & M & & Respiratory & 5 yrs & \\
\hline Mean $( \pm S D)$ & & 53 yrs (14) & UL 72\%; LL 16\%; Resp 12\% & 7.5 yrs $(7.6)$ & \\
\hline
\end{tabular}


M: Male; F: Female, UL: Upper Limb; LL: Lower Limb; U: Unknown 


\section{Figure 1: Pedigree of the family}

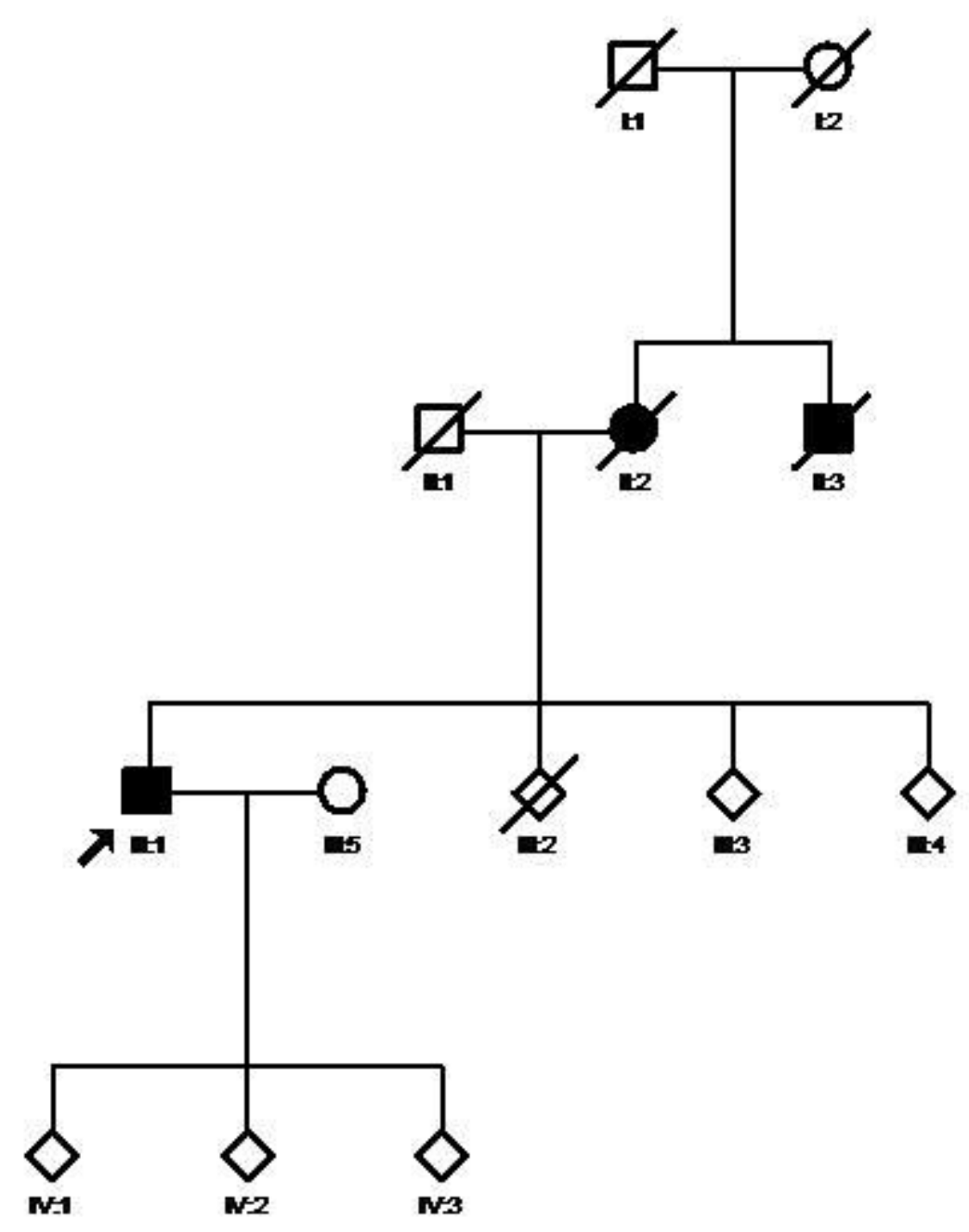


Figure 2: DNA sequence of the patient III:1 with the mutation L144F

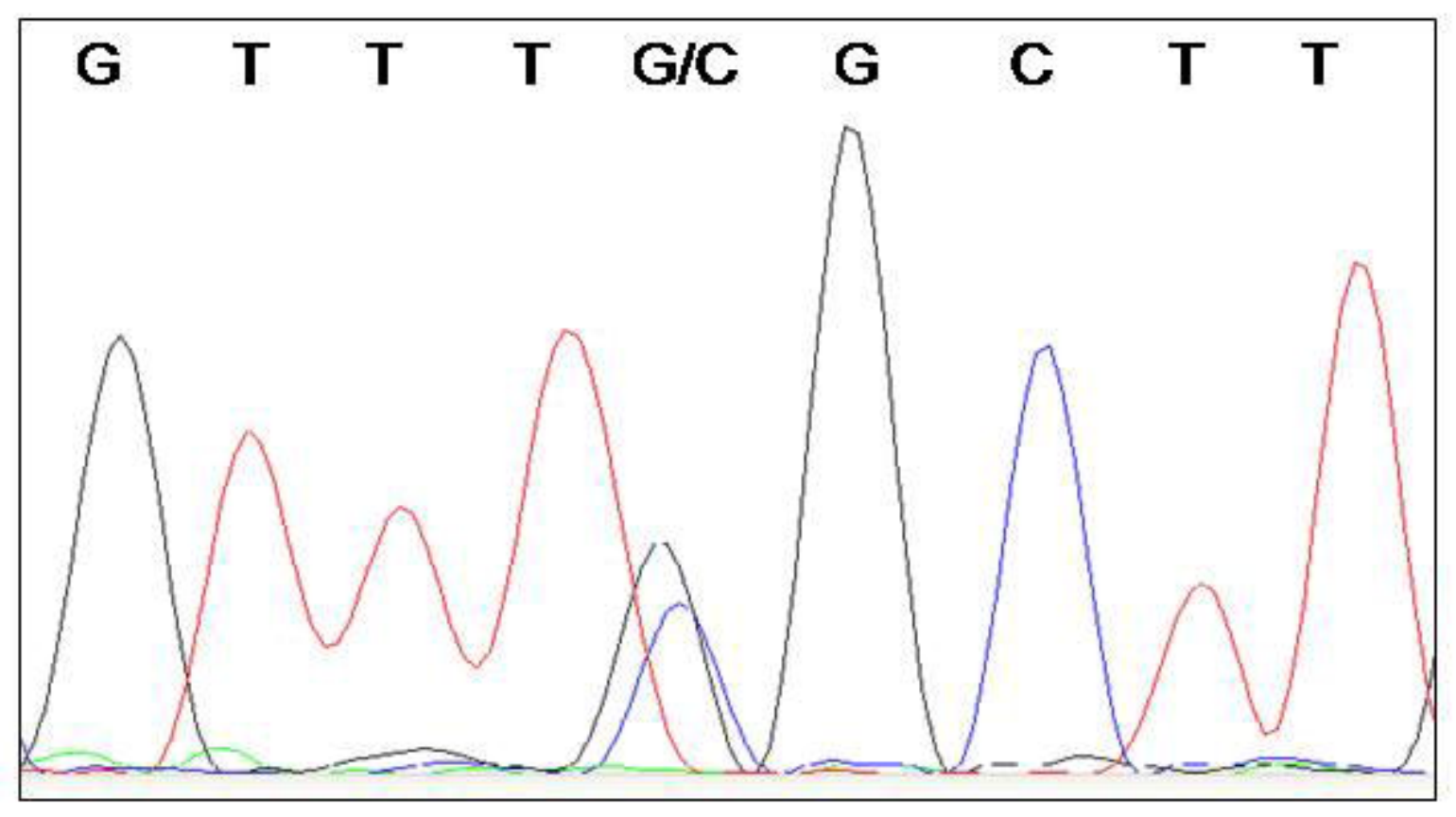

